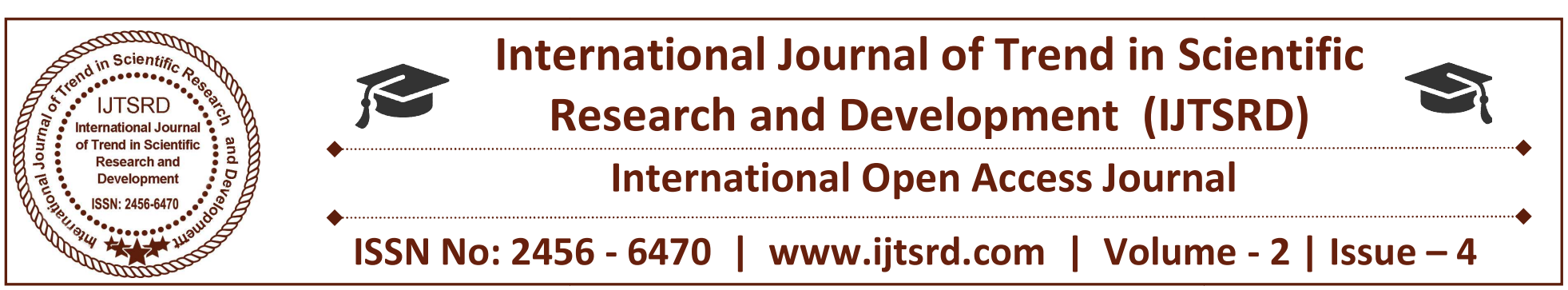

\title{
An Empirical View of Influence Marketing from Influencers and Influence Marketers
}

\author{
${ }^{1}$ Dr. R. Anuja, ${ }^{2}$ D. M. Lavanya \\ ${ }^{1}$ Principal, ${ }^{2}$ Assistant Professor, Department of Management Studies \\ KG College of Arts and Science, Coimbatore, Tamil Nadu, India
}

\begin{abstract}
The present study is an effort to know the current trend of the influential marketing. Influencers come in many ways, either online or web celebrity or even the other customers. Influencers can play a role in each moment of truth during the customer journey through content, engagement and community. It is by engaging influencers in authentic, long-term relationships and creating value within the relationships between influencers 17 and their communities, that CMOs can impact sales, satisfaction, retention and overall customer experience. The true potential of influence marketing on social networks rests on the quality of relationships developed with influencers. Influential marketing strategies must be focused on the customer's contextual experience and then proposes to reinvent the mapping of the consumer's journey, based on content that is centered on the needs of the customers and distributed by influencers and ambassadors. "There is no more B2B or B2C: It's Human to Human, $\# \mathrm{H} 2 \mathrm{H}$. Social and marketing need to work together to personalize individual conversations, as well as deliver shared global experiences that crowds of common values can benefit from and this is what our social and digital mediums have gifted us, and how humans interact and feel more compelled to take action." Many companies are now investing their efforts and resources into influence marketing thus the current study was proposed with a sample of 180 respondents in Coimbatore to know the marketers and influencers view on influencial marketing.
\end{abstract}

Keywords: Ambassadors, Influential

\section{INTRODUCTION}

Influencer marketing focuses on using key leaders to drive their brand's message to the larger market segment. In other words, it helps you concentrate on the central figures in marketing rather than focusing on marketing as a niche. These key leaders can be anyone from A-list celebrities to Instagram stars and Vloggers. Influencer marketing relies on technology; whereby influencers are expected to spread the word through their personal social channels. There is no denying that traditional ads are no longer as appealing to consumers as they once were. With so many ads popping out on print, electronic and social media, consumers are left with no choice but to ignore or block them. Influencer marketing is proving its value as an effective marketing tool better than the traditional Ads. Whereas conventional ads are no longer as effective because ad blockers are becoming increasingly popular and easy to use. Influencer marketing leverages the popularity and trend-setting power of influencers. For example, you saw your favorite celebrity sharing a post in which she mentioned buying her favorite jeans and affiliation to that particular brand. The next day, you went out to buy the same brand thinking that it would be cool. Influencer marketing is having a critical impact on brand marketing and this trend is being followed by not only big celebrities, but also by small boutiques and businesses. In the 2000s, social marketing was the hot trend, then came content marketing and today, it is influencer marketing. After all, nothing influences a person more than another person, and what could be more influencing than famous celebrities? The core theme behind influencer marketing is to get individuals with a fan following and make them 
endorse your brand. Sounds simple, doesn't it? The beginning of 2017 has seen many consumers relying on social media and reviews when buying a product.

\section{STATEMENT OF PROBLEM}

One of the factors felt important to choose the topic is to study the growth of influential marketing in 2017. In today's trend, an influencer plays a vital role rather than a celebrity. A celebrity was known even before social media. Whereas, an influencer is respected for being herself/ himself. Both have the ability to push forward your brand to their respected followers.

\section{OBJECTIVES OF THE STUDY}

The present study proposed the following objectives

$>$ To know the importance of influencer marketing from the point of view of both marketers and influencers.

$>$ To identify the most effective forms of influencer marketing from the point of view of both marketers and influencers.

$>$ To recognize the type of influencers most successful.

$>$ To investigate the challenges of the marketers in working with the influencers.

$>$ To know the effective ways in which the brands work with the influencers.

\section{RESEARCH METHODOLOGY}

The data used for the study is primary data through a set of questionnaire circulated among the marketers and influencers from a sample of 180 respondents each.

\section{REVIEW OF LITERATURE}

During the course of the study, the study of several authors was referred and it is imperative that an outline of the literature survey is put to note and the following references are worth mentioning.

[1] Brian Solis,2015 in the study" Why The Future of Influencer Marketing Starts With People And Relationships Not Popularity"

[2]"Josephine hardy"inthe influencer marketing statistics", 2016 " has made a study and has analysed that Google trends shows the growth of influencer marketing over traditional marketing strategies
[3] Kimberlee Morrison, April 26, 2017” Instagram Dominates Influencer Marketing (Report)" analyzed that $99.3 \%$ of influencers said Instagram was a great place to connect with community and brands.

[4] Lee Odden , 2017 " The Future of Influencer Marketing Research Report" had surveyed over 100 enterprise level marketers and brand strategists from companies including Microsoft, American Express and $3 \mathrm{M}$ and found that Brands need to evolve their view of influencer marketing from short term transactional engagements to a more strategic and holistic view that emphasizes long term influencer relationships.

[5] Tomoson , 2015 in "A survey" emphasizes how influencer marketing can be highly lucrative for those brands who engage in it and the businesses are making $\$ 6.50$ for every $\$ 1$ spent on influencer marketing and $59 \%$ of micro-influencers think Instagram is the most effective social media platform to engage their target audience."

\section{ANALYSIS AND FINDINGS}

Influencer marketing is further aided by the fact the online consumers are preferably keeping a distance from most forms of ads. As such, eating at a restaurant or even places to visit. But, things began to favor influencer marketing several years ago. Back in 2015, Lord \& Taylor, a well-known department store collaborated with 50 Instagrammers and asked them to post a picture of themselves wearing a specific dress on a specific day and in exchange, the Instagrammers would be receiving a $\$ 1000-\$ 4000$ incentive. As a result, the campaign reached a total of 11.4 million Instagram users, with about 328,000 brand engagements on Lord \& Taylor's account. This specific dress was sold out in no time.

\section{TABLE NO.1}

\section{Showing Why the Marketers Feel Influencer} Marketing is Important

\begin{tabular}{|l|l|}
\hline FACTOR & RANK \\
\hline More authentic storytelling for our brand & 2 \\
\hline Better reach to consumers & 2.22 \\
\hline $\begin{array}{l}\text { Offers a better return on invest-ment than } \\
\text { my other marketing channels }\end{array}$ & 3.5 \\
\hline $\begin{array}{l}\text { Makes our brand feel more plugged into } \\
\text { digital communities }\end{array}$ & 3 \\
\hline $\begin{array}{l}\text { A good alternative to traditional advertising } \\
\text { efforts }\end{array}$ & 4.04 \\
\hline Helps us reach Millennials and Centennials & 4.14 \\
\hline
\end{tabular}


International Journal of Trend in Scientific Research and Development (IJTSRD) ISSN: 2456-6470

(Rank in order of importance, $1=$ most important) The data shows good alignment between what's important to marketers and influencer's authenticity.

TABLE NO.2

Showing what keeps influencers engaged

\begin{tabular}{|l|l|l|}
\hline PARTICULARS & $\begin{array}{l}\text { NO. OF } \\
\text { RESPOND } \\
\text { ENTS }\end{array}$ & $\begin{array}{l}\text { RESPOND } \\
\text { ENTS (\%) }\end{array}$ \\
\hline Other & 5 & $20 \%$ \\
\hline Post and stay on top & 15 & $10 \%$ \\
\hline $\begin{array}{l}\text { Interact \& respond } \\
\text { online }\end{array}$ & 4 & $15 \%$ \\
\hline Provide value & 5 & $64 \%$ \\
\hline Honest & 71 & $71 \%$ \\
\hline
\end{tabular}

The data shows good alignment between what's important to marketers and influencers genuineness. Genuineness is at the heart of engagement in the social web. Authentic engagement over time is how we earn trust online (and in the real world). Marketers view authentic storytelling as the most important aspect of influencer marketing. Influencers believe that it's an honest and authentic voice that keeps their audience engaged (71\%). But more so, authenticity has to be the foundation for consistently delivering value to and engaging with communities.

TABLE NO.3

Showing the most effective forms of influencer marketing for the marketer

\begin{tabular}{|l|l|l|}
\hline FORMS & $\begin{array}{l}\text { NO. OF } \\
\text { RESPOND } \\
\text { ENTS }\end{array}$ & $\begin{array}{l}\text { RESPONDE } \\
\text { NTS (\%) }\end{array}$ \\
\hline Affiliate links & 10 & $10 \%$ \\
\hline Other & 10 & $10 \%$ \\
\hline Sponsored content & 50 & $50 \%$ \\
\hline Event coverage & 5 & $5 \%$ \\
\hline Brand mentions & 15 & $15 \%$ \\
\hline Product reviews & 20 & $20 \%$ \\
\hline $\begin{array}{l}\text { On-going } \\
\text { ambassadorships }\end{array}$ & 70 & $70 \%$ \\
\hline
\end{tabular}

"Brands cite ambassadorships as the most effective use of influencers."
TABLE NO.4

Showing the ways in which the brands typically reach the audience for an influencer

\begin{tabular}{|l|l|l|}
\hline WAYS & $\begin{array}{l}\text { NO. OF } \\
\text { RESPONDE } \\
\text { NTS }\end{array}$ & $\begin{array}{l}\text { RESPONDEN } \\
\text { TS (\%) }\end{array}$ \\
\hline Other & 10 & $10 \%$ \\
\hline Affiliate links & 12 & $12 \%$ \\
\hline Ambassadorships & 52.5 & $52.5 \%$ \\
\hline Product reviews & 25 & $25 \%$ \\
\hline Sponsored content & 80 & $80 \%$ \\
\hline
\end{tabular}

As you can see, there is some disconnect here between what marketers perceive as the most effective form of engagement and how they actually engage influencers. Only 50\% of brands see sponsored content as an especially effective means of influencer marketing, yet it is the most commonly reported type of engagement among influencers $(80 \%)$. While product reviews are an area where there is alignment, brands cite ambassadorships as the most effective use of influencers (25\%), yet they are among the lesser-used engagements $(53 \%)$.

\section{TABLE NO.5}

Showing the type of influencers found to be most successful

\begin{tabular}{|l|l|}
\hline SUCCESSFUL ASPECT & $\begin{array}{l}\text { Rating } \\
\text { Average }\end{array}$ \\
\hline $\begin{array}{l}\text { A popular person with a significant and } \\
\text { desirable audience }\end{array}$ & 2.82 \\
\hline $\begin{array}{l}\text { Those who are subject matter experts } \\
\text { regardless of follower count }\end{array}$ & 3.25 \\
\hline Those who act as ongoing ambassadors & 3.35 \\
\hline Those who have a large following & 4.43 \\
\hline \begin{tabular}{l} 
Those who are highly active online \\
\hline $\begin{array}{l}\text { Anyone who actively talks about our } \\
\text { market or brand }\end{array}$
\end{tabular} & 5.83 \\
\hline $\begin{array}{l}\text { Those who are focused on a single } \\
\text { platform }\end{array}$ & 6.64 \\
\hline A real world celebrity & 6.70 \\
\hline $\begin{array}{l}\text { Someone who always talks about } \\
\text { competitors }\end{array}$ & 7.83 \\
\hline
\end{tabular}

(Rank in order of importance, $1=$ most important) 
Influence isn't necessarily tied to popularity. According to influencer marketers, a large following is not necessarily a predictor of success in influencer marketing. It's also important to consider how well your brand, market, or product will resonate with a given influencer's audience. Marketers reported that they were more successful when working with influencers who are prolific on a variety of channels, as opposed to those who limit themselves to predominantly one platform or medium.

TABLE NO.6

Showing the marketers challenges in working with influencers

\begin{tabular}{|c|c|c|}
\hline CHALLENGES & $\begin{array}{l}\text { NO. OF } \\
\text { RESPONDE } \\
\text { NTS }\end{array}$ & $\begin{array}{l}\text { RESPONDE } \\
\text { NTS }(\%)\end{array}$ \\
\hline Other & 5 & $5 \%$ \\
\hline $\begin{array}{l}\text { Communicating } \\
\text { on assignment }\end{array}$ & 2 & $2 \%$ \\
\hline $\begin{array}{l}\text { Overall } \\
\text { management of } \\
\text { 3rd party content } \\
\text { creators }\end{array}$ & 25 & $25 \%$ \\
\hline $\begin{array}{l}\text { Negotiating } \\
\text { terms }\end{array}$ & $\leq 0$ & $5 \%$ temation \\
\hline $\begin{array}{l}\text { Finding ways } \\
\text { while satisfying } \\
\text { executive } \\
\text { expectations }\end{array}$ & $\begin{array}{r}9 \\
\end{array}$ & Deve \\
\hline $\begin{array}{l}\text { Finding relevant } \\
\text { influencers }\end{array}$ & & \\
\hline
\end{tabular}

The biggest barriers to working with influencers gyrates more or less in choosing who and how to engage. $78 \%$ of respondents indicated that they struggle to source influencers who are relevant to their organization or specific objectives. $65 \%$ of marketers find it difficult to balance the needs of the influencer and his or her community against leadership's expectations for ROI and performance. It's also interesting that almost a third (25\%) of marketers cite everyday management of influencers and content as a challenge. Thus the marketers have to consider program management and metrics ahead of any program and get buy-in from executives and influencers alike."The biggest barriers to working with influencers revolve around choosing who and how to engage"
TABLE NO.7

Showing what challenges does influencer marketing face within the organization

\begin{tabular}{|l|l|l|}
\hline $\begin{array}{l}\text { CHALLENG } \\
\text { CHALLENGES }\end{array}$ & $\begin{array}{l}\text { NO. OF } \\
\text { RESPONDEN } \\
\text { TS }\end{array}$ & $\begin{array}{l}\text { PERCENTAG } \\
\text { E OF } \\
\text { RESPONDEN } \\
\text { TS (\%) }\end{array}$ \\
\hline Other & 10 & $10 \%$ \\
\hline $\begin{array}{l}\text { Lack of control } \\
\text { over messaging }\end{array}$ & 20 & $20 \%$ \\
\hline $\begin{array}{l}\text { Unaware of what } \\
\text { it is }\end{array}$ & 42 & $42 \%$ \\
\hline $\begin{array}{l}\text { No budget } \\
\text { assigned }\end{array}$ & 53 & $53 \%$ \\
\hline $\begin{array}{l}\text { Concern since } \\
\text { it's unproven } \\
\text { channel }\end{array}$ & 55 & $55 \%$ \\
\hline
\end{tabular}

Influencer marketing faces challenges that are not unlike other emerging forms of digital, social and mobile marketing. More effort needs to be taken in helping executives understand how influencer marketing actually influencers markets, conversations and decisions. Considering that all of the challenges represent that it's new; executives don't know what it is, how to value or believe in it and thus budgets are not established accordingly. However, for those that are already familiar with it, $41 \%$ of marketers cite lack of control over messaging as a challenge.

\section{Influencers}

TABLE NO.8

Showing what are some of the biggest mistakes brands/agencies make in working with influencers

\begin{tabular}{|l|l|l|}
\hline MISTAKES & $\begin{array}{l}\text { NO. OF } \\
\text { RESPONDEN } \\
\text { TS }\end{array}$ & RESPOND \\
ENTS (\%) \\
\hline Other & 16 & $16.7 \%$ \\
\hline $\begin{array}{l}\text { Requiring drafts for } \\
\text { every post }\end{array}$ & 24 & $24.5 \%$ \\
\hline $\begin{array}{l}\text { Requiring too many } \\
\text { social shares or } \\
\text { sharing to every } \\
\text { social channel }\end{array}$ & 28 & $28 \%$ \\
\hline $\begin{array}{l}\text { Not providing } \\
\text { adequate time }\end{array}$ & 32 & $32 \%$ \\
\hline $\begin{array}{l}\text { Overly restrictive } \\
\text { content guidelines }\end{array}$ & 39 & $39.4 \%$ \\
\hline $\begin{array}{l}\text { Not of adering } \\
\text { adequate } \\
\text { compensation }\end{array}$ & 72 & $72.2 \%$ \\
\hline
\end{tabular}


Influencer marketing is new and faces many challenges. On the marketing front, it's unproven, which requires pilot programs to demonstrate capabilities and shape future budgets and expectations. At the same time without pushing influencer marketing strategies into new frontiers where influence (cause and effect) becomes vital, the ROI potential can't be achieved. Brands want to control messaging and content, and influencers feel that marketers are too controlling. This is a key point to highlight, influencers are followed because of their authenticity, and brands stated this is their number one priority. Clearly, controlling the message is counterproductive.

TABLE NO.9

Showing the tactics used by marketers manage influencers

\begin{tabular}{|c|c|c|}
\hline TACTICS & $\begin{array}{l}\text { NO. OF } \\
\text { RESPONDEN } \\
\text { TS }\end{array}$ & $\begin{array}{l}\text { RESPONDE } \\
\text { NTS }(\%)\end{array}$ \\
\hline $\begin{array}{ll}\text { use } & \text { an } \\
\text { influencer } \\
\text { directory }\end{array}$ & $47 \bigcirc$ & $\begin{array}{l}47 \% \text { IJ } \\
\text { Internati }\end{array}$ \\
\hline Other & 8 & $8 \%$ \\
\hline $\begin{array}{l}\text { use influencer } \\
\text { marketing } \\
\text { solution in } \\
\text { handling the } \\
\text { details }\end{array}$ & है & $\begin{array}{l}\text { 28\% reno } \\
\text { Rese } \\
\text { Deve }\end{array}$ \\
\hline $\begin{array}{l}\text { use agency to } \\
\text { handle }\end{array}$ & 20 & $20 \%$ \\
\hline $\begin{array}{l}\text { Work directly } \\
\text { with influencer }\end{array}$ & 77 & \\
\hline
\end{tabular}

Marketers succeed in interacting directly with influencers - their preferred means of managing an engagement $(77 \%)$. The influencers are also very much interested in working through PR agencies (63\%) and influencer marketing platforms (27\%). With automated solutions only a year old, brands haven't fully caught on to the myriad ways of successfully sourcing and managing influencers. By taking the influencer perspective, this will improve efficiencies and expand management scenarios.
TABLE NO.10

Showing the most effective ways in which brands work with influencers

\begin{tabular}{|c|c|c|}
\hline $\begin{array}{l}\text { EFFECTIVE } \\
\text { WAYS }\end{array}$ & $\begin{array}{l}\text { NO. OF } \\
\text { RESPOND } \\
\text { ENTS }\end{array}$ & $\begin{array}{l}\text { RESPONDENT } \\
\text { S }(\%)\end{array}$ \\
\hline Other & 2 & $2 \%$ \\
\hline $\begin{array}{l}\text { Through ad } \\
\text { agency }\end{array}$ & 5 & $5 \%$ \\
\hline Through an agent & 5 & $5 \%$ \\
\hline $\begin{array}{l}\text { Through an } \\
\text { influencer } \\
\text { marketing } \\
\text { platform }\end{array}$ & 27 & $27 \%$ \\
\hline $\begin{array}{l}\text { Through a PR } \\
\text { agency or } \\
\text { influencer } \\
\text { marketing agency }\end{array}$ & 78 & $78 \%$ \\
\hline Brand direct & 63 & $63 \%$ \\
\hline
\end{tabular}

"Influencers are also very receptive to working through PR agencies and influencer marketing platforms."

TABLE NO.11

Showing the data used for measuring the success of influencers efforts

\begin{tabular}{|l|l|}
\hline DATA & RANK \\
\hline $\begin{array}{l}\text { Engagement (comments on a blog } \\
\text { post, likes, shares, etc on social) }\end{array}$ & 2.89 \\
\hline Brand awereness & 3.87 \\
\hline Sales lift & 4.11 \\
\hline Traffic & 4.67 \\
\hline Reach & 4.74 \\
\hline Share of voice & 5.07 \\
\hline Sentiment & 5.28 \\
\hline Impression & 5.37 \\
\hline
\end{tabular}

(Rank in order of importance, 1 = most important)

As a third party, influencers lack access to the analytics at a campaign's completion. Because of this, they see an increase in traffic as the best measure of success in their work with brands, while brands are rightly looking at engagement on social as well as other 'brand awareness' Given that influencer marketing most often resides within the social marketing team (28\%) it makes sense. But the ROI of influencer marketing can be vastly improved by first 
defining the " $\mathrm{R}$ " (return) as related to cause and effect against a current measured state.

\begin{tabular}{|l|l|}
\hline PLATFORMS & RANK \\
\hline Personal Blog & 2.45 \\
\hline Facebook & 3.09 \\
\hline Instagram & 3.49 \\
\hline Twitter & 3.63 \\
\hline Pinterest & 4.26 \\
\hline Youtube & 5.95 \\
\hline LinkedIn & 7.22 \\
\hline Snapchat & 7.56 \\
\hline Vine & 8.12 \\
\hline Medium & 9.24 \\
\hline
\end{tabular}

TABLE NO.12

Showing how do influencers measure the success in their work with brands

\begin{tabular}{|l|c|}
\hline \multicolumn{1}{|c|}{ MIEASURE } & RANK \\
\hline Traffic & 3.21 \\
\hline $\begin{array}{l}\text { Shares of your post to social } \\
\text { channels }\end{array}$ & 3.62 \\
\hline $\begin{array}{l}\text { Re-engagement from brand for } \\
\text { additional assignments }\end{array}$ & 3.83 \\
\hline Impressions & 3.84 \\
\hline Likes (or the equivalent) & 3.86 \\
\hline Comments & 4.74 \\
\hline Brand mentions & 4.89 \\
\hline
\end{tabular}

(Rank in order of relevance, 1 = most relevant)

"The ROI of influencer/marketing can be vastly improved by first defining the "R" (return)as related to cause and effect against a current measured state."

TABLE NO.13

\section{Showing the Platforms for Influencer Marketing} from marketers view

\begin{tabular}{|l|l|}
\hline PLATFORMS & RANK \\
\hline Facebook & 3.22 \\
\hline Twitter & 3.36 \\
\hline Youtube & 3.91 \\
\hline Facebook & 4.26 \\
\hline Twitter & 4.43 \\
\hline Instagram & 5.78 \\
\hline Pinterest & 6.11 \\
\hline Vine & 8.02 \\
\hline Medium & 8.33 \\
\hline
\end{tabular}

(Rank in order of importance 1 Most Important 10Least Important)

\section{Showing the Popular Platforms for Influencer Marketing from influencers view}

Facebook, Twitter, Instagram, and YouTube are all in the top ranks for the most popular influencer platforms. While brands and influencers are generally in alignment on which platforms are important on social, they should be aware that influencers see their personal blogs as \#1 above all other channels. Yes, blogs still matter!

\section{FINDINGS \\ Discussion of the Results}

1. Marketers view authentic storytelling as the most important aspect of influencer marketing. Influencers believe on the honest and genuine voice that keeps their audience engaged.

2. Brands cite ambassadorships as the most effective use of influencers.

3. Marketers reported that they were more successful when working with influencers who are prolific on a variety of channels, as opposed to those who limit themselves to predominantly one platform or medium.

\section{SUGGESTIONS}

Influencer marketing is the perfect way of marketing a product or service without making them feel offended. Though most online consumers gladly participate and become a part of influencer marketing campaigns, it has to be done with honesty and must not be with vengeance.

\section{SCOPE OF THE STUDY}

The role of Influencer marketing plays a vital role for India in its march towards 2020 and the future ahead. Influential marketing for FMCG products and health industry plays a vital role which has to be studied.

\section{CONCLUSION}

Influencer marketing is the next big thing because it works in ways that typical celebrity endorsements or traditional content strategies missed - the ability to elicit peer-to-peer action. In social media, celebrities and creators can indeed influence. In its own research, Twitter and analytics firm Annalect found that consumers now trust digital influencers nearly as much as their real world friends. Majority of the respondents have purchased an item online after seeing it used by an influencer on Instagram, Twitter, Vine or YouTube. On Niche, a company Twitter 
acquired last year that develops content on Vine, Instagram and other social platforms, the number of influencers in the pool to choose from has grown from 6,000 to more than 24,000 in a year. Average deal size has also gone up, increasing $250 \%$ with the number of monthly campaigns skyrocketing $300 \%$.It's time to be more thoughtful and selective about influencer marketing. Now that influencer marketing is part of the everyday mix, it's time to push it forward, try bolder experiments and push engagement in ways that help brands and influencers communicate authentically and effectively for the benefit of all involved. To succeed, marketers must respect influencers as well as the power of influence and the value of social capital. The goal of any good marketer should be to connect brand promise and value to consumer want/need and aspiration and also to help influencers increase social capital among their communities.

\section{REFERENCES}

1. Brian Solis,,"Altimeter @prophet-infographiccan-celebrity-endorse sales.

2. Josephine hardy, Acorn Influence Company blog.
3. Kimberlee Morrison, 2017" social pro daily" homepage courtesy of Rocky89/iStock.

4. Lee Odden,2017 "Top rank marketing blog" Pg.09.

5. Tomoson, 2016 "Business news daily" Micro influencers,Pg.1-3.

\section{BIBLIOGRAPHY}

1. "Business Research methods" Donald R Cooper \& Pamela S Schindler, 9th Edition, McGraw Hill, (2006).

2. "Essentials of Human Resource Management and Industrial relations" SubbaRao, Himalaya Publishing House, Mumbai, (2005).

3. "Statistics for management" S G Guptha, Sulthan Chand \& Sons, 33rd Edition (2012).

4. Ministry of External Affairs (2015), India in Business, Investment and Technology Promotion Division, Govt. of India.

5. Department of Agriculture and Cooperation, Ministry of Agriculture, Govt. of India. 